\title{
Implementation of Issuance of Certificates to Replace Property Rights on Land Due to Loss Based on Government Regulation Number 24 of 1997
}

\author{
Lily Kalyana ${ }^{1}$, Megawati Barthos ${ }^{2}$ \\ \{lilykalyana@yahoo.com ${ }^{1}$, megawati_barthos@borobudur.ac.id ${ }^{2}$ \} \\ Universitas Borobudur, Jakarta, Indonesia ${ }^{1,2}$
}

\begin{abstract}
Based on government regulation No. 24 of 1997, this article examines the use of controlling certificates to replace ownership rights on land that have been lost. A normative legal approach was applied in this research. Primary and secondary data were used. Primary data is gathered mostly through direct interviews with informants, whereas secondary data comprises primary, secondary, and tertiary legal resources. The results of the Land background are obtained based on this investigation, which includes applying for a certificate of loss from the police, a letter of application, the applicant's identity, and an affidavit of swearing from the applicant before the Head of the Land Office.
\end{abstract}

Keywords: Property Rights; Publishing; Land; Lost

\section{Introduction}

After clothing and food, land and housing are the most basic needs, and land plays a significant role in the dynamics of development. According to Article 33 paragraph (3) of the Republic of Indonesia's 1945 Constitution, the state controls the ground, water, and natural resources contained within it and uses them for the people's greatest benefit. Because there is a growing need for land for community benefit. The government has emphasized the importance of registering land rights, as well as obtaining building permits, to provide protection and legal certainty to its citizens' rights to land and houses, both individual and public rights to land and houses. As a result, regulation is needed to ensure legal certainty and protection for holders of land rights, so that there is order in the utilization or use of land.

The government has enacted legislation to regulate the land, among other things, with the passage of Law No. 5 of 1960 on Basic Agrarian Regulations and Government Regulation No. 24 of 1997 on Land Registration [1]. To maintain and ensure the legal certainty of its residents' rights to land and housing, both individual and public rights, the government has emphasized the importance of registering land rights, as well as getting building licenses for landowners, so that there is order in the exploitation or use of land. To regulate the land, the government has implemented regulations such as Law No. 5 of 1960 on Basic Agrarian Regulations and Government Regulation No. 24 of 1997 on Land Registration [2].

Land registration is defined as "a series of activities carried out continuously, sustainably, and regularly, including the collection, processing, bookkeeping, and presentation and 
maintenance of concrete data and juridical data, in the form of maps and a list of land parcels and apartment units, including the issuance of certificates as proof of their rights for land parcels," accordance to the rules of State Regulation Number 24 of 1997, Article 1 paragraph 1. "A certificate is a letter of proof of rights that applies as a strong proof of evidence regarding physical data and juridical data contained therein, as long as the physical data and juridical data follow the data provided by the government that is in the letter of measurement and the land book concerned," according to Article 32 paragraph (1) of Government Regulation Number 24 of 1997.

As a result, the legislation-confirmed certificate of land rights is a letter of confirmation of rights with legal power as a strong proof of possession of land rights. The land registration system demonstrates the legal force of land rights certificates as proof of ownership of land rights. The registration of deeds and the registration of titles are the two types of land registration systems. Indonesia employs the registration of titles system, which was first employed in the implementation of land registration under PP 10/1961. Because land registration is so important, both the registrar and the community are asked to work together to achieve the land registration's key goals.

The certificate is indeed proof of a land right which is also recorded in the relevant land book. If a land title certificate is lost, a new certificate can be issued as a replacement as regulated in Government Regulation No. 24/1997 on Land Registration (PP 24/1997).

Land rights holders' ownership of land certificates changes over time, and difficulties with their certificates are common. Land certificates, on the other hand, are critical and serve as substantial evidence of ownership of land rights. Such issues include, for example, the destruction of land rights certificates as a result of natural disasters or damage caused by old paper, or the certificate being shredded owing to the holder's carelessness, rendering the certificate useless. Apart from certificate damage, another issue that certificate holders confront is lost certificates whose whereabouts are unclear, which is extremely detrimental to land rights holders.

In the event of loss, a substitute property document is given in the same way that a land title certificate or a replacement certificate is issued in the event of damage. However, prior to issuing a replacement certificate due to loss, research must be conducted on the legal data pertaining to the plot of land and media statements. This is done to prevent the lost certificate from being misused and to prevent the applicant for a replacement certificate from committing fraud as a result of the loss. Based on government rule No. 24 of 1997, this article covers the adoption of controlling warranties to replace land ownership in the event of bankruptcy.

\section{Methodology}

This study employs a qualitative technique in conjunction with a normative legal procedure [3]. A literature review is performed to gather data in order to get in-depth and thorough information [4]. The data is then subjected to a descriptive analysis in order to portray it in its entirety.

\section{Results and Discussion}

Cadastre (Dutch: Cadastre) is the specific term for a document that specifies the size, value, and occupancy (or other rights) of a piece of land. It is employed in the registration of 
land. This word comes from the Latin "capistratum," which refers to a Roman land tax record, capita, or unit (Capotatio Terrens). Cadastre, in its most basic form, is a record of lands, their worth, and the people who own them. It is also used for tax purposes. As a result, Cadastre is a useful instrument for providing a description and identification of the description, as well as a continuous recording of land rights [1].

Article 1 point 1 of Government Regulation Number 24 of 1997 defines new land registration as "a series of activities carried out by the government on a continuous, continuous, and regular basis, including the collection, processing, bookkeeping, and presentation and maintenance of physical and juridical data in the form of maps and lists, regarding land parcels and apartment units, including the provision of proof of title for land parcels". Property authorization is defined as a refinement of the reach of property registration actions as defined in Constitutional and statutory sentence (2) of State Regulation Number 10 of 1961, which only mainly contains quantification, routing, and recordkeeping, property laws and handover, and providing proof of rights as a shred of prominent evidence. The following definition can be used to define the elements of land registration [5]:

a. There is a series of activities. The words "a series of activities" refer to the existence of various activities in the implementation of land registration, which are related to one another, sequentially into a unified series which leads to the availability of the necessary data to guarantee legal certainty in the land sector for the people. Land registration activities consist of land registration activities for the first time, Its activities include the collection and processing of physical data, proof of rights and bookkeeping, issuance of certificates, presentation of physical data and juridical data, storage of general registers and documents, and registration of transfers and assignment of rights, as well as registration of changes to other land registration data. Physical and legal data are generated as a result of land registration processes. Information describing the location, limitations, and area of registered land parcels and apartment units, as well as information about the existence of buildings or parts of buildings above them, is referred to as physical data. Judicial data refers to information regarding the legal status of registered land parcels and flats, their rights holders, and other parties, as well as the liabilities they face.

b. This is under the control of the government. Land registration is a government function in contemporary civilization, carried out for the betterment of the public in order to provide constitutional clarity inside the plain area.

c. Continuously, sustainable. The terms "continuously, sustainably" allude to the implementation of operations that will continue indefinitely after they have begun. The data that has been collected and available must always be maintained, in the sense of being adapted to changes that occur later until it remains following the last state. Activities land registration for the first time produces proof of rights in the form of certificates. In the land registration activities, there can be a transfer of rights, Assignment of rights, outgrowth of a term of land ownership; division, separation, and combining of landed properties; allocation of joint rights; nullification of land ownership and private property for housing units; transfer and cancellation of mortgage rights; changes in land registration data based on court decisions or decisions; and changes in the name of the right holder must all be registered with the local Regency/Municipal Land Office until the latest version of the law is followed.

d. Regularly. The word "regular" indicates that all activities must be based on appropriate laws and regulations because the results will be evidence according to law, even though the power of proof is not always the same in the laws of countries that carry out land registration. 
e. Land plots and apartment units Ownership Rights, Business Use Rights, Building Use Rights, Use Rights, Management Rights, Waqf Land, Ownership Rights to Flat Units, Mortgage Rights, and State Land are all registered.

f. Proof of rights is provided. For the first time, land registration activities provide certificates of evidence of rights in the form of certificates on already-owned land parcels and certificates of ownership of flats. The certificate is a certificate of proof of rights for land rights, management rights, waqf land, property rights to flat units, and mortgage rights, as defined in Article 19 paragraph (2) letter c of the BAL, each of which has been registered in the applicable land book.

g. He is burdened with certain rights. Ownership Rights, Cultivation Rights, Building Use Rights, Use Rights, and Ownership Rights to Flat Units as collateral for debts with encumbered Mortgage Rights, or Ownership Rights to land encumbered with Right to Use Building or Right to Use may be encumbered with other rights in the land registration.

Elucidation of Article 2 PP No. 24 of 1997 stipulates that the principle of land registration is: [6]

a. The Basic Principle. It is aimed also that also said and practices in the implementation of land registration could be comprehended by the relevant parties, particularly the owners of land ownership.

b. Safe Principle. Land authorization is supposed to be done meticulously so that the results can provide legal certainty assurances, which is the goal of land registration. According to the wording of Sections 32 PP no. 24 of 1997, a certificate is a certificate of proof of rights that serves as evidence for the physical and jurisdictional information contained in it, as long as the physical and juridical data follow the data $\mathrm{c}$ in the carried letter of measurement and the book of land rights issued concerned. That the legal and physical data shown in the diploma should be considered correct data in both daily legal activities and court disputes if the data follows what is indicated in the letter of measurement and the land book, unless it has been demonstrated otherwise. If a land certificate has indeed been lawfully authorised in the names of the people or government body that obtained and limits the territory in bad faith, the other party who believes he does have rights to land can no longer demand the exercise of those protections if he does not file a written objection to the certificate with the Head of the Land Office concerned within 5 (five) years of the certificate's issuance or does not file a lawsuit in court regarding land tenure. That a person who does not claim his land, which was certified on behalf of a person or private corporation, but who do not file a reason to object to the certificate and the Face of the Land Administrator, or a court civil suit, inside of 5 (five) decades of a certificate's issuing, while the land was obtained in earnest or mechanically governed by him or another individual or private corporation to his approval.

c. Affordable Principle. It shows that the parties can afford to pay attention to the needs and capabilities of those who are economically disadvantaged. Land registration services must be affordable to those who require them. According to paragraph (4) of Article 19 of the UUPA, which states that those who cannot afford to pay fees are exempt, the government regulates the costs of land registration.

d. Advanced Principle. It refers to the accuracy of implementation and the consistency with which land registration data is maintained. The available information must reflect current conditions, necessitating compliance with the need to register and record modifications that occur later. The registration is continuous, which means it is updated regularly. 
e. Open Principle. It implies that land registration information must be updated on a regular basis. The data in the Land Office reflects the precise circumstances on the field at all times, and the public has access to the records anywhere at period.

Issuance of certificates to replace land rights due to loss at the Land Office can be done in the following ways [7] :

a. Make a cover letter from the Village that the land certificate is lost. The first thing to do if the land certificate is lost is to make a cover letter from the RT (Neighborhood Association) or RW (Citizen Association) to be given to the Village. Then the Village party will make a cover letter to be submitted to the police regarding the loss of the land certificate. There is no charge for this cover letter.

b. Reporting to the Police Station that the Land Certificate is Lost. Report to the police station at the local police level that the land certificate has been lost by bringing a cover letter from the local Village. Then the cop will issue a letter of loss as a document in the form of a Minutes of Investigation, which will be attached when reporting the loss of a certificate to the Land Office.

c. Property Licenses are being blocked. If the preparation of the Minutes of Investigation from the police takes a long time, the landowner must immediately send a letter of request for stopping the land certificate to the Land Office. To have a land certificate blocked, the landowner must go to the Land Office with important papers such as a photocopy of the land certificate and proof of the identification of the land certificate's owner. If the Land Office receives the block letter and records it in the land book, the land certificate in question is safe, and other parties cannot do anything with the land until an application for the issuing of a new certificate is made.

d. Reporting Loss of Certificate to the Land Office. After the issuance of the report of loss from the police station, the next step is to report the loss of the certificate of title to the land to the Land Office so that a replacement certificate or a second certificate can be issued. The reporter must bring the following requirements:

e. Oath Taking. After all the conditions have been met, the Land Office will contact the interested party in this case, The landowner must take the certificate owner oath in front of the Land Office's Head and Clergy according with religion of the party concerned, and also the Land Office will record the swear in a Minutes of Oath.

f. The announcement in Print Media. Furthermore, the Land Office will announce the Minutes of Oath Taking for the loss of the land certificate in the print media. This announcement is made to give time to parties who object to the issuance of the replacement document or if there are objections or claims from other parties.

g. Land Re-measurement. The land will be re-measured by officials from the Land Office, and a replacement certificate will be given. If the old measurement letter and the present physical condition of the land and buildings differ, this is done.

h. Issuance of Substitute CertificatesSuppose within 30 (thirty) days from the announcement in the print media and no party raises an objection or claim on creating a replacement certificate, or some parties file a complaint. Still, according to the Head of the Land Office, the objection is unfounded or unfounded. In that case, the Land Office will issue a certificate of replacement for the land rights [8]. Issuing certificates to replace land rights due to loss has several positive impacts on the community, namely by issuing certificates to replace land rights due to loss, it proves that the community knows that certificates of land rights are crucial and are sturdy means of proof. 


\section{Conclusion}

Implementation of the Issuance of Certificates to Replace Land Rights Due to Loss Related to Government Law Article 24 of 1997 Concerning Land Registration, namely in applying for the issuance of certificates of replacement of land rights due to loss at the Land Office, fees must be paid according to Government Regulation Number 128 of 2015 Concerning Types and Tariffs of Non-Tax State Revenues Applicable to the Ministry of Agrarian Affairs and Sp.

\section{References}

[1] B. Harsono, Hukum Agraria Indonesia, Sejarah Pembentukan Undang-Undang Pokok Agraria, Isi dan Pelaksanaannya. Jakarta: Djambatan, 1999.

[2] N. Setyawan and E. Israhadi, "Implementation of Basic Agrarian Law No. 5/1960 in Indigenous Land Disputes in Malinau District," 2021, doi: 10.4108/eai.6-32021.2306466.

[3] M. Abdul Kadir, "Hukum Dan Penelitian Hukum.," Bandung PT. Citra Aditya Bakti., 2015.

[4] M. H. Dr. johnny ibrahim,SH., Teori \& Metodologi Penelitian Hukum Normatif. 2006.

[5] B. Harsono, Hukum Agraria Indonesia. Jakarta: Djambatan, 2005.

[6] Soetomo, Pedoman Jual Beli Tanah Peralihan Hak dan Sertipikat. Malang: Lembaga Penerbitan Universitas Brawijaya, 1981.

[7] U. Santoso, Hukum Agraria dan Hak-hak Atas Tanah. Jakarta: Kencana Prenadamedia Group, 2007.

[8] R. Rahman, "Konflik Masyarakat Dengan Pemerintah (Studi Kasus Sengketa Tanah Adat)," Sosioreligius, vol. 2, no. 1, pp. 41-48, 2017. 